\title{
Sosialisasi Potensi Keberagaman dan Semangat Toleransi di Kelurahan Sulamu Kabupaten Kupang
}

\author{
Socialization of the Potential of Diversity and the Spirit of Tolerance in Sulamu of \\ Kupang Regency
}

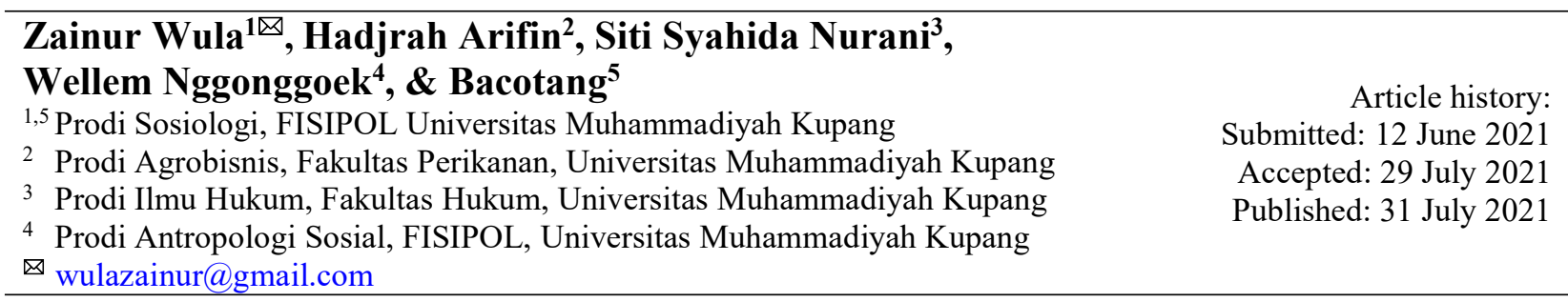

Abstract: Multicultural diversity is a fact of life that exists in Indonesian people's lives which is the greatest gift of God should be maintained. By engaging the Bajo tribal community in the Sulamu village of Kupang, province East Nusa Tenggara, who share the livelihood in the village with people of different tribes and religions, this community service is methodologically carried out by doing socialization. The important objective of the socialization was to obtain the communal understanding within the Bajo ethnic community about the potential for diversity in order to realize the spirit of tolerance in Sulamu Village. By participating in the program, the Bajo people, who are all Muslims in religion, gain knowledge in increasing their insight into thinking and realizing harmonious relationships and mutual understanding in building peace, unity, integrity, and prosperity.

Keywords: community unity; multicultural diversity; Sulamu Kupang; tolerance.

Abstrak: Keberagaman multikultural merupakan fakta kehidupan yang ada dalam kehidupan masyarakat Indonesia dan merupakan anugerah Tuhan yang paling besar untuk dijaga. Dengan melibatkan masyarakat Suku Bajo di Desa Sulamu Kupang Provinsi Nusa Tenggara Timur yang hidup di desa tersebut dengan masyarakat beragam suku dan agama, program ini dilakukan dengan melakukan sosialisasi. Tujuan penting dari sosialisasi tersebut adalah untuk memperoleh pemahaman komunal dalam masyarakat etnis Bajo tentang potensi keragaman dalam rangka mewujudkan semangat toleransi di Desa Sulamu. Dengan mengikuti program tersebut, masyarakat Bajo yang beragama Islam memperoleh pengetahuan dalam meningkatkan wawasan berpikir dan mewujudkan hubungan yang harmonis dan saling pengertian dalam membangun perdamaian, persatuan, kesatuan, dan kesejahteraan.

Kata Kunci: keragaman multikultural; persatuan komunitas; Sulamu Kupang; toleransi. 


\section{Pendahuluan}

Manusia adalah makhluk sosial (homo socius), yang mana antara satu dengan lainnya saling membutuhkan dan melengkapi. Kondisi seperti ini menuntut tiap orang untuk selalu bekerja sama dan bertanggungjawab dengan dan pada yang lain. Kondisi ini bisa kita temukan juga di negara Indonesia, karena Indonesia merupakan negara multikultural dan sangat beragam dilihat dari aspek sosial budaya, adat istiadat dan agama serta latar belakang lainnnya (Lestari, 2015). Secara sosiologis bahwa multikulturalisme dalam tataran konsep dan realitas kehidupan kebangsaan patut kita hargai dan terima sebagai anugerah Tuhan Yang Maha Esa. Namun demikian dalam realitas kehidupan masyarakat, masalah yang berkaitan dengan multikulturalisme masih belum sepenuhnya dilakukan oleh individu, masyarakat dan bangsa, sehingga masih ada kecurigaan satu sama lain, intoleransi dan sebagainya, dan bahkan terjadi konflik suku agama ras dan antar golongan (SARA) di mana-mana.

Menurut El Muhtaj (2016), suku agama ras dan antar golongan (SARA) adalah berbagai pandangan dan tindakan yang didasarkan pada sentimen identitas yang menyangkut keturunan, agama, kebangsaan atau kesukuan dan golongan. Sementara itu, Simmel dalam Binmore (2010) menyatakan bahwa agama ibarat dua sisi mata uang yang sama dalam kohesi dan konsensus, artinya di satu sisi, bisa menumbuhkan solidaritas sosial dan integrasi bangsa. Secara politis, agama memainkan peran serupa dengan kebangsaan yang memposisikan agama sebagai alat pemersatu dari sekian banyak etnis yang beragam. Namun pada sisi yang lain, agama kerap kali dipolitisasi dan tidak jarang justru menimbulkan perpecahan, ketegangan, dan konflik.

Menurut Coser dalam Laleye (2011), ada keagresifan atau bermusuhan dalam diri orang, dan dia memperhatikan bahwa dalam hubungan intim dan tertutup, antara cinta dan rasa benci hadir, sehingga masyarakat akan selalu mengalami situasi konflik. Oleh karena itu, Coser membedakan dua tipe dasar konflik antara yang realistik dan non realistik. Sebagaimana Simmel, Coser melihat konflik dan integrasi sebagai dua sisi yang saling memperkuat atau memperlemah satu sama lain. Konflik realistik memiliki sumber yang kongkrit atau bersifat material, seperti sengketa sumber ekonomi atau wilayah. Jika mereka telah memperoleh sumber sengketa itu, dan bila dapat diperoleh tanpa perkelahian, maka konflik akan segera diatasi dengan baik. Sementara itu, konflik non realistik didorong oleh keinginan yang tidak rasional dan cenderung bersifat ideologis, seperti konflik antar agama, antar etnis, dan konflik antar kepercayaan lainnya. Antara konflik yang pertama dan kedua, konflik yang non realistiklah yang cenderung sulit untuk menemukan solusi atau sulit mencapai konsensus dan perdamaian.

Konflik yang mengatasnamakan agama dan suku akhir-akhir ini semakin marak di tanah air. Maraknya kekerasan semacam ini menunjukkan bahwa kesatuan dan persatuan bangsa saat ini sedang diuji eksistensinya (Setiawan \& Amal, 2016). Pada hakikatnya, agama seharusnya dapat menjadi pendorong bagi umat manusia untuk selalu menegakkan perdamaian dan meningkatkan kesejahteraan bagi seluruh umat di bumi, namun realitanya agama justru menjadi salah satu penyebab terjadinya kekerasan dan kehancuran umat manusia. Oleh karena itu, diperlukan upayaupaya preventif agar masalah pertentangan agama tidak akan terulang lagi di masa yang akan datang. Misalnya, dengan mengintensifkan forum-forum dialog antar umat beragama dan aliran kepercayaan (dialog antar iman), membangun pemahaman keagamaan yang lebih pluralis dan inklusif, serta memberikan pendidikan tentang pluralisme dan toleransi beragama melalui 
berbagai metode yang mungkin dilakukan di tengah masyarakat (Sahfutra, 2019; Setyawan, 2020).

Menurut Durkheim (2017), agama sangat penting bagi seseorang untuk menghindarkan dari berbagai penyimpangan yang mungkin terjadi dimana unsur-unsur esensial dari agama itu mencakup berbagai mitos, dogma, dan ritual, yang kesemuanya merupakan fenomena religius yang dihadapi manusia. Dalam kaitan ini, ada hal-hal yang sifatnya 'suci' (sacred) dan juga ada hal-hal yang sifatnya 'tidak suci' (profane) yang pemisahan antara keduanya menunjukkan kepada pemikiran-pemikiran religius yang dilakukan manusia. Bagi Durkheim, moralitas itu merupakan suatu aturan yang merupakan patokan bagi tindakan dan perilaku manusia (juga dalam berinteraksi). Konsep mengenai moralitas ini merujuk pada apa yang dinamakan norms (norma-norma) dan rules (aturan-aturan) yang harus dijadikan acuan dalam berinteraksi untuk mewujudkan perdamaian. Menurut Sutarno (2007), pembangunan perdamaian merupakan suatu kata yang digunakan untuk menjelaskan proses dan usaha untuk meningkatkan kehidupan ekonomi, politik, budaya, dan infrastruktur masyarakat, serta menuju perdamaian dan sebagainya yang merupakan hasrat bagi setiap orang untuk mewujudkan impian hidup yang tenang berdampingan antara satu dengan yang lainnya.

Oleh karena itu, program pengabdian masyarakat ini dilakukan dengan tujuan menjadi salah satu upaya untuk membangun perdamaian tersebut. Dilaksanakan oleh tim pengabdi dari Universitas Muhammadiyah Kupang, program ini ditujukan pada masyarakat etnik Bajo yang tinggal di Kelurahan Sulamu, Kecamatan Sulamu, Kabupaten Kupang, Provinsi Nusa Tenggara Timur. Kelurahan yang terletak di Pulau Timor, tepatnya di Teluk Kupang, dapat dikatakan sebagai salah satu kelurahan multikultural karena terdiri dari beragam suku dan agama. Kelurahan Sulamu merupakan salah satu kampung yang cukup padat penduduknya, berjumlah sebanyak total 5047 jiwa yang terdiri dari laki-laki sebanyak 2533 jiwa dan perempuan sebanyak 2514 jiwa dari 1338 kepala keluarga (KK). Dari aspek keagamaan, mayoritas penduduk beragama Kristen Protestan dan sebagian lainnya Katolik atau Islam (Gambar 1), sedangkan dari aspek etnik yang merupakan mayoritas adalah suku Rote atau Bajo, dan sisanya suku DawanTimor, Helong, Sabu dan Flores serta suku lainnya.

\section{Persebaran penduduk Kel. Sulamu berdasarkan ragam agama}

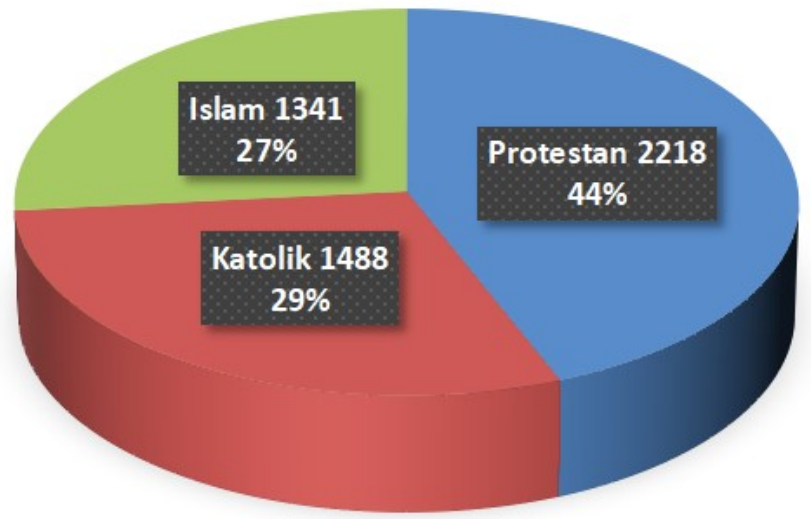

Gambar 1. Diagram persebaran penduduk Sulamu berdasarkan agama 
Suku Bajo merupakan etnik terbesar kedua di kelurahan Sulamu, secara kuantitatif jumlah kepala keluarga suku Bajo sebanyak 395 dengan jumlah penduduk 1533 jiwa dan tinggal di enam RT terpadat, yakni di RT 12, 13, 14, 15, 16, dan 17. Etnik Bajo bermigrasi dari Sulawesi Tenggara dan tinggal di wilayah Sulamu sejak puluhan tahun silam dengan profesi pekerjaan pokok sebagai nelayan. Hampir seluruh etnik Bajo merupakan pemeluk agama Islam, berbeda dengan etnik lainnya, yakni Rote, Dawan, Helong dan Sabu yang mayoritas merupakan pemeluk agama Kristen Protestan atau Katolik. Di Kelurahan Sulamu, khususnya di sekitar konsentrasi masyarakat Bajo, terdapat dua masjid yakni Masjid Al-Ikhlas dan Masjid Al-Amin. Oleh karena itu, tim pengabdi dari Universitas Muhammadiyah Kupang yang terdiri dari Zainur Wula, Hadjrah Arifin, Siti Syahida Nurani, Wellem Nggonggoek dan Bacotang melaksanakan program pengabdian ini di lokasi tersebut.

Argumentasi dasar yang dijadikan tim pengabdi adalah bahwa keberagaman merupakan anugerah Tuhan Yang Maha Kuasa dan menjadi sumber kekuatan dalam pembangunan peradaban manusia secara keseluruhan di wilayah Sulamu. Namun, jika keberagaman ini tidak dikelola secara baik dan terjadi perbedaan pandangan, sikap, pergaulan dan hubungan interaksi yang kurang baik, dapat melahirkan hal-hal yang tidak diinginkan, maka stabilitas hidup masyarakat menjadi terganggu. Ini menjadi poin penting agar masyarakat mendapatkan pencerahan dan penyegaran pola pikir dalam peningkatan hubungan interaksi dan harmonisasi sosial, sehingga dapat meningkatkan persatuan dan kesatuan masyarakat untuk mencapai kesejahteraan hidup.

\section{Metode Pengabdian}

Dalam melaksanakan kegiatan pengabdian kepada masyarakat di kelurahan Sulamu dengan fokus pada etnik masyarakat suku Bajo, kegiatan dilakukan di masjid Al-Ikhlas dan Masjid Al-Amin pada 28 Desember 2020 dengan mensosialisasikan pentingnya peningkatan toleransi antar hidup beragama menuju terwujudnya persatuan dan kesatuan masyarakat multikultural (Gambar 2). Dengan melakukan ceramah, diskusi dan tanya jawab, program pengabdian ini diharapkan dapat meningkatkan pengetahuan dan pemahaman masyarakat dalam memahami keberagaman etnik, agama, dan aspek sosial budaya masyarakat yang berbeda-beda di Sulamu.
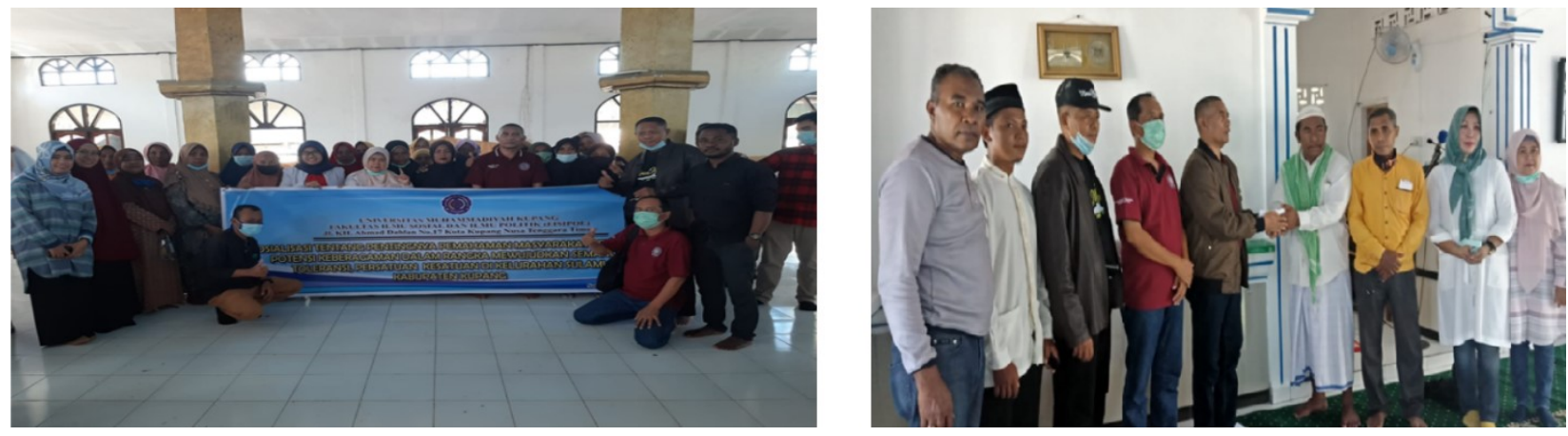

Gambar 2. Foto bersama setelah dilakukan sosialisasi di Masjid Al-Ikhlas (kiri) dan Masjid Al-Amin (kanan). 


\section{Pelaksanaan}

Langkah-langkah yang dilakukan selama sosialisasi, yakni ceramah, diskusi, dan tanya jawab difokuskan pada bebarapa isu penting tentang bagaimana masyarakat memahami, menghayati, menghargai, dan mengamalkan dalam kehidupan sehari-hari.

\section{Ceramah}

\section{Memahami Kondisi Keberagaman dalam Masyarakat}

Dalam kegiatan ini (Gambar 3) dijelaskan keberagaman atau yang sering disebut dengan pluralitas kehidupan merupakan sunnatullah yang harus diterima, dihormati dan didayagunakan oleh masyarakat. Keberagaman merupakan salah satu bukti kebesaran Allah Swt Tuhan Yang Maha Pengasih dan Penyayang (Purwanto, 2012). Tema ini dijelaskan kepada masyarakat suku Bajo agar memahami bahwa masyarakat kita memiliki perbedaan latar belakang antara lain keyakinan/agama, suku, budaya dan adat istiadat. Dijelaskan pula kepada masyarakat bahwa meskipun kita berbeda akan hal itu, tetapi dalam kehidupan harus saling tolong menolong dan bersilaturahmi antara satu dengan yang lainnya untuk meningkatkan kesejahteraan hidup masyarakat.
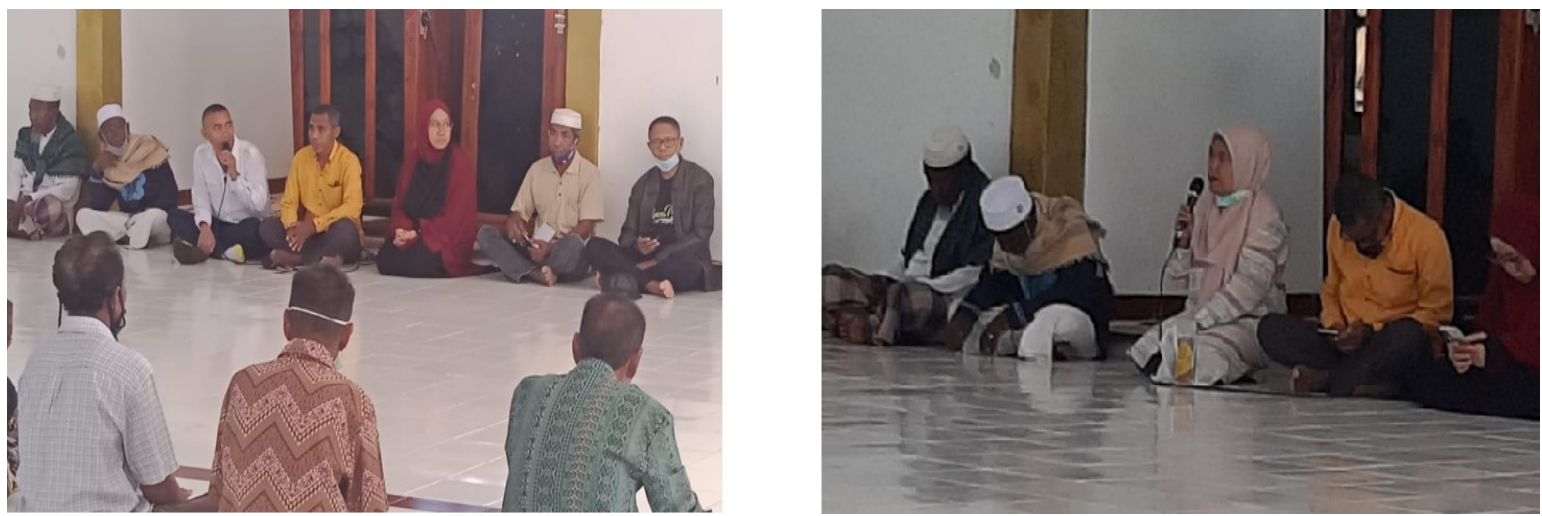

Gambar 3. Tim Pengabdian sedang menyampaikan ceramah

Kita tidak bisa hidup sendiri tanpa orang lain, jadi yang ditekankan dalam masyarakat adalah sikap saling ketergantungan antara satu dengan yang lainnya sehingga diperlukan hidup yang rukun agar tercipta sikap toleransi akan perbedaan untuk meningkatkan persatuan dan kesatuan masyarakat. Selain manusia mempunyai sejumlah perbedaan, manusia juga mempunyai sejumlah kesamaan yakni dilahirkan dalam keadaan suci (fitrah), memerlukan kebutuhan primer dan sekunder, mendambakan ketenangan dan kedamaian, memerlukan orang lain dalam kehidupan, ingin dicintai/mencintai, dihargai/menghargai, diperhatikan/memperhatikan, menyukai keindahan, menyukai kebebasan, serta memiliki keterbatasan dalam berfikir dan bertindak, dan meskipun kadarnya berbeda, memiliki rasa takut, gembira, sedih, bahagia, dan kecewa. 


\section{Selalu Mengembangkan Dialog Jika Ada Perbedaan Pendapat}

Kegiatan sosialisasi dilakukan kepada masyarakat suku Bajo di kelurahan Sulamu dengan penekanan pada bagaimana cara menyelesaikan setiap perbedaan pendapat dan pandangan. Sebagai contoh kontekstual adalah bahwa setiap tahun pemerintah menyelenggarakan pembangunan sosial kemasyarakatan dengan berbagai program dan dana untuk pembangunan fisik dan non fisik dalam rangka meningkatkan kualitas hidup masyarakat. Namun dalam pelaksanaannya sering terjadi perbedaan pandangan, sehingga kami menyarankan jika ditemukan perbedaan dalam hal pemikiran dan sikap, maka harus dilakukan dengan dialog agar tercapai kesepakatan sehingga pembangunan bisa berjalan.

Demikian pula dengan perbedaan pendapat dalam pembangunan kesejahteraan seperti Bantuan Langsung Tunai (BLT) dan Program Keluarga Harapan (PKH) dalam rangka meningkatkan taraf hidup dan kesejahteraan keluarga dan masyarakat yang rawan terjadi perbedaan pendapat, misalnya berkaitan dengan jumlah warga miskin, kriteria yang digunakan, ukuran penghasilan dan jenis pekerjaan. Oleh karena itu, tim pengabdi menyarankan agar setiap perbedaan pendapat dapat diselesaikan dengan baik agar terciptanya kerukunan sosial sehingga upaya yang dilakukan pemerintah dapat terwujud menemui sasaran dan masyarakat dapat meningkatkan kesejahteraannya secara layak.

\section{Selalu Mengedepankan Prasangka Baik}

Agar terwujudnya persatuan dan kesatuan masyarakat yang berbeda latar belakang sosial budaya suku, agama dan antar golongan, perlu dikembangkan sikap saling percaya satu sama lain. Berbagai bentuk prasangka yang membahayakan masyarakat harus dihilangkan sehingga kerukunan selalu terpelihara dengan baik. Dalam kehidupan keseharian, harus dikembangkan pula saling percaya antar satu dengan yang lainnya, sikap hidup saling menghargai dan hidup berdampingan serta perlu dijauhinya sikap saling mencurigai antar satu dengan yang lainnya. Jika ada permasalahan atau yang perlu dipertanyakan, maka harus dikedepankan sikap dialog dan membangun saling pengertian di antara komponen masyarakat tersebut.

\section{Selalu Mengembangkan Sikap Solidaritas}

Di antara hal yang selama ini memang sudah ada dan berkembang, tetapi perlu terus ditingkatkan, adalah berkaitan dengan solidaritas dalam membangun kebersamaan. Sikap hidup saling tolong menolong untuk kebaikan bersama, terutama jika ada yang memerlukan bantuan atau jika ada melihat orang lain mengalami kesulitan, sangat penting untuk dipupuk di lingkungan masyarakat multikultural sebagaimana di Sulamu. Dengan solidaritas, maka dapat terwujud kesetiakawanan dan kekompakan yang mendorong seseorang atau kelompok orang di Sulamu untuk ikut merasakan penderitaan tetangganya yang mengalami kesulitan tanpa melihat simbol-simbol yang melekat pada pribadinya seperti suku, agama dan kelas sosial. Kami juga terus mendorong agar terus ditumbuhkembangkan sikap tenggang rasa antara satu dengan yang lainnnya serta kerelaan untuk mengakui dan menghormati kelebihan maupun kekurangan orang lain. Dengan cara 
seperti ini, akan terus terwujud toleransi dan harmonisasi kehidupan meskipun masyarakatnya berbeda-beda suku dan budaya.

\section{Diskusi dan Tanya Jawab}

Langkah berikutnya yang kami lakukan adalah dengan melakukan diskusi dan tanya jawab (Gambar 4). Dalam sesi ini, masyarakat suku Bajo Sulamu menunjukkan antusiasme karena mereka disediakan tempat untuk berbagi pengalaman dalam kehidupannya sehari-hari. Terdapat beberapa pertanyaan terkait materi di antaranya adalah, "Bagaimana jika diundang oleh tetangga yang berbeda keyakinan, misalkan undangan untuk Tasyakuran?", yang diungkap oleh Tetua Adat Bajo, yang tidak berkenan disebut namanya dalam publikasi ini, karena sering diundang dalam acara kelahiran oleh masyarakat dari suku maupun agama lain. Dijawab oleh pengabdi dengan menerangkan bahwa undangan tasyakuran tersebut boleh, bahkan penting untuk dihadiri karena termasuk bagian muamalah yang merekatkan persatuan.
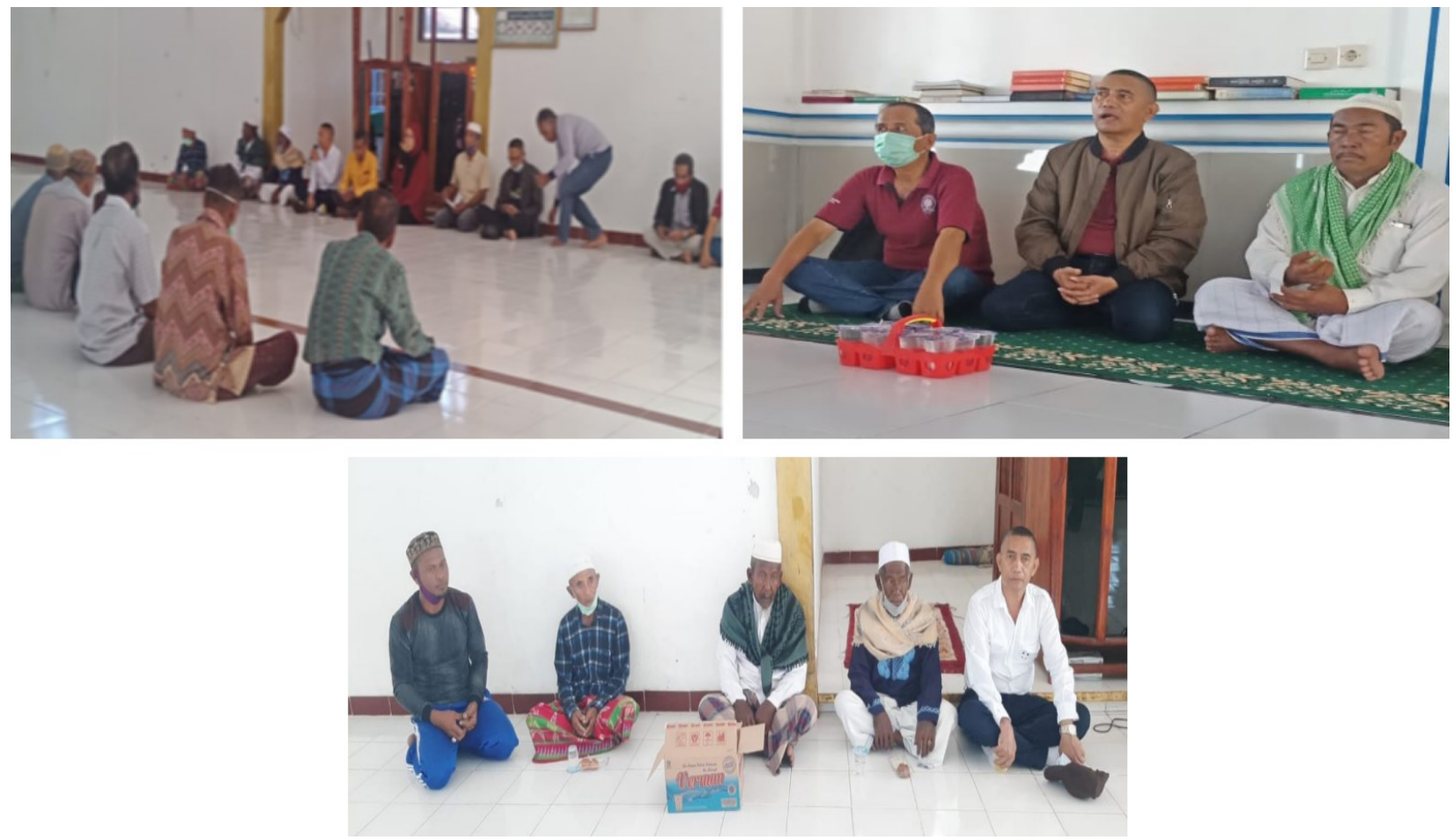

Gambar 4. Suasana diskusi dan tanya jawab

Pertanyaan lain yang muncul dari warga masyarakat bernama Udin Wase adalah, "Bagaimana kalau ada anggota masyarakat yang soliter dan tidak mau bergaul karena introvert?". Pertanyaan ini kemudian dijawab oleh pengabdi bahwa hal ini merupakan sikap pribadi tiap individu, yang walaupun kurang baik tetapi tetap dapat diterima selama tidak membuat tindakan kriminal.

Dalam diskusi yang diikuti lebih dari 40 orang ini berkembang banyak pemikiran masyarakat tentang keberagaman, yang menurut Tetua Adat Bajo sekaligus Ketua Lingkungan, bahwa "Masyarakat suku Bajo ini sudah terbiasa bergaul antar suku maupun antar keyakinan, hingga di Sulamu tidak ada yang mempersoalkan tentang perbedaan-perbedaan dengan sangat 
tajam". Pernyataan ini dibenarkan oleh pengabdi, "Terkait beda SARA adalah hal yang biasa diketemukan sejak zaman nenek moyang dan berlangsung harmonis, namun perkembangan zaman yang cepat dapat menjadikan pandangan dapat berubah, misalnya dengan maraknya indoktrinasi online dari kelompok teroris. Ini yang berbahaya."

Ada juga ungkapan dari penanya lain, di antaranya mahasiswa yang asli Bajo, Ramon, yang menyatakan, "Yang sering membesar-besarkan perbedaan itu 'kan orang-orang pintar, bagi kami masyarakat dengan keterbatasan pengetahuan, kami tidak akan peduli (perbedaan itu), kami sudah saling kenal mengenal satu sama lain, kami selalu tolong menolong, saling meminjam uang dan meminta bantuan orang lain, tetangga, meskipun yang berbeda keyakinan dan sosial budaya pada saat mengalami kesulitan." Ungkapan itu kemudian diapresiasi pengabdi dengan menyampaikan, "Kami sangat mengapresiasi hubungan interaksi sosial budaya dalam keberagaman itu ternyata sudah dipraktikkan dalam kehidupan sehari-hari di Sulamu sehingga terbina kerukunan antar umat beragama. Mari kita jaga semangat toleransi untuk semakin meningkatkan persatuan dan kesatuan.”

\section{Kesimpulan}

Sosialisasi tentang pentingnya pemahaman masyarakat etnik Bajo terhadap potensi keberagaman dalam rangka mewujudkan semangat toleransi, persatuan dan kesatuan di Kelurahan Sulamu pada tanggal 28 Desember 2020 ini mendapat apresiasi yang sangat tinggi dari masyarakat. Masyarakat yang sangat beragam mendapat banyak hal dalam meningkatkan wawasan berpikir untuk meningkatkan hubungan interaksi sosial budaya yang harmoni dalam mewujudkan persatuan dan kedamaian di Sulamu.

Dengan sosialisasi, masyarakat semakin menyadari betapa penting hidup toleransi, membangun saling pengertian dan keterbukaan serta meningkatkan kesetiakawanan sosial dalam mewujudkan kesejahteraan masyarakat di tengah ragam etnik, agama, dan latar belakang sosial budaya. Masyarakat semakin menyadari bahwa hidup dengan semangat toleransi dan tidak saling mencurigai satu sama lainnya adalah modal penting untuk mewujudkan persatuan dan kesatuan masyarakat di Sulamu.

\section{Referensi}

Binmore, K. (2010). Social norms or social preferences?. Mind \& Society, 9(2), 139-157. https://doi.org/10.1007/s11299-010-0073-2

Durkheim, E. (2017). The Elementary Forms of the Religious Life. The Free Press.

El Muhtaj, M. (2016). Resensi Buku "Kewargaan Multikultural; Teori Liberal Mengenai Hak-hak Minoritas". HUMANITAS: Jurnal Kajian dan Pendidikan HAM, 7(2), 105-115. https://doi.org/10.24114/hpu.v7i2.10918

Laleye, S. (2011). Democracy in Conflict and Conflicts in Democracy: The Nigerian Experience. Cultura, 8(1), 127-142. https://doi.org/10.2478/v10193-011-0008-x

Lestari, G. (2015). Bhinnekha Tunggal Ika: Khasanah Multikultural Indonesia Di Tengah Kehidupan SARA. Jurnal Ilmiah Pendidikan Pancasila Dan Kewarganegaraan, 28(1). http://dx.doi.org/10.17977/jppkn.v28i1.5437

Purwanto, A. (2012). Nalar Ayat-Ayat Semesta. Mizan Pustaka. 
Sahfutra, S. (2019). Konflik dan Bina Damai Masyarakat Multirelijius: Studi Masyarakat Turgo Lereng Merapi Yogyakarta. MUHARRIK: Jurnal Dakwah Dan Sosial, 2(2), 71-97. https://doi.org/10.5281/zenodo.3540507

Setiawan, D., \& Amal, B. K. (2016). Membangun Pemahaman Multikultural dan Multiagama Guna Menangkal Radikalisme di Aceh Singkil. Al Ulum, 16(2), 349. https://doi.org/10.30603/au.v16i2.155

Setyawan, A. (2020). Dakwah yang Menyelamatkan: Memaknai Ulang Hakikat dan Tujuan Da'wah Islamiyah. Al-Adabiya: Jurnal Kebudayaan Dan Keagamaan, 15(02), 189-199. https://doi.org/10.37680/adabiya.v15i02.487

Sutarno. (2007). Pendidikan Multikultural. Kalimantan Selatan: Dinas Pendidikan dan FKIP Unlam. 